\title{
THE WOOD ANATOMY OF GARDENIEAE, IXOREAE AND MUSSAENDEAE (RUBIACEAE)
}

\author{
JIFKE KOEK-NOORMAN
}

Instituut voor Systematische Plantkunde, Utrecht

\section{SUMMARY}

The tribe Gardenieae in the restricted delimitation proposed by Bremekamp and Verdcourt is wood anatomically homogeneous. The genera of the Ixoreae studied by me also agree with each other in wood structure. Within the tribe Mussaendeae in the delimitation accepted by Schumann the wood anatomy shows much variation. The tribe becomes more homogeneous, if some of the genera included in this tribe by Schumann are removed. The systematic position of some genera, which in the literature are said to be related to Gardenieae, Ixoreae or Mussaendeae, is discussed in the light of similarities and differences in the wood anatomy.

\section{INTRODUCTION}

The classification of the Rubiaceae presented by SCHUMANN in ENGLeR \& PrantL's "Die natürlichen Pflanzenfamilien' (1897) is not the first one, but was preceded by several other ones. A survey of the work of his predecessors was given by BREMEKAMP (1966).

Schumann divided the Rubiaceae into two subfamilies, the Cinchonoideae and the Coffeoideae. The tribes Gardenieae and Mussaendeae were placed, near each other, in the Cinchonoideae, whereas the Ixoreae were included in the Coffeoideae. VERDCOURT (1958) distinguished three subfamilies and classified the three tribes in one of them, the Cinchonoideae. BREMEKAMP (1966), who divided the Cinchonoideae sensu Verdcourt into two subfamilies, mainly based upon the presence or absence of the 'ixoroid' pollination mechanism, placed the Ixoreae and the Gardenieae in the Ixoroideae, the Mussaendeae in the Cinchonoideae (see Koek-NoORMAN 1969 b, p. 378). Halle $(1961,1967)$ did not go into the classification of the family, but considered the Gardenieae, Ixoreae and Mussaendeae to be closely related. STEYERMARK $(1965,1967)$ accepted the Gardenieae, Ixoreae and Mussaendeae, but did not give his ideas on the delimitation of these tribes and on the position they occupy in the family.

In a preceding paper (KoEK-NoORMAN 1970) I suggested that the wood anatomy of the tribes referred by Bremekamp to the Cinchonoideae should be regarded as less homogeneous than that of the tribes included by him in the Ixoroideae. The purpose of the present investigation is to detect whether data obtained from a study of the wood anatomy of the genera concerned can contribute to the discussion on the delimitation and on the position of these tribes in the family. 


\section{MATERIAL AND METHODS}

The methods applied by me have been described in a preceding paper (KoEKNOORMAN 1969a). The material studied by me is listed at the end of the present paper. The main results of the investigation are listed in table 1 .

\section{DIsCussion}

3.1. Discussion of the anatomical data obtained in the present investigation and of those found in the literature

\subsubsection{Gardenieae}

Material of the following genera, the classification of which in the Gardenieae is not disputed in the literature, was available: Alibertia, Amajoua, Amaralia, Borojoa, Casasia, Duroia, Galiniera, Gardenia, Genipa, Ibetralia, Kotchubaea, Leptactinia, Randia, Rosenbergiodendron, Rothmannia, Stachyarrhena.

Besides, I have been able to study slides made from samples of Burchellia bubalina (L.f.) Sims., Dictyandra arborescens Welw., Diplospora malaccensis Hook. f. and D. viridiflora DC., Gardenia coronaria Ham., G. latifolia Schum., and G. norae Swynn., Morelia senegalensis A. Rich., Oxyanthus formosus Hook. f. and $O$. unilocularis Hiern., Scyphiphora hydrophyllacea Gaertn., Randia densiflora Bth., R. exaltata Griff., and R. micrantha DC., Rothmannia lutea (Willd.) Ken., Stachyarrhena heterochroa Standl., which are present in the slide collections of the Jodrell Laboratory, Kew, and in those of the Commonwealth Forest Research Institute, Oxford. Furthermore, material of the following genera, the inclusion of which in the Gardenieae is disputed in the literature, was available: Aulacocalyx, Bertiera, Hamelia, Heinsia, Hillia, Pentagonia, Posoqueria, Retiniphyllum, Tarenna, Tricalysia.

The data obtained during the present investigation suggest a rather high degree of homogeneity in the wood anatomy of the first mentioned group of Gardenieae (i.e. of those genera the inclusion of which in this tribe is generally accepted): the vessels are either exclusively solitary or partly arranged in short radial multiples, and their diameter varies from 40-100 $\mu$. (Plate I; see also KoeK-Noorman 1969a, Plate I, II, IV, VI, VII and VIII). The fibre tissue consists of thick-walled fibre tracheids with bordered pits on the tangential and radial walls. The rays are uniseriate in some species, but mostly 1- to 4-seriate, with a low multiseriate central part and high uniseriate margins. The axial parenchyma is predominantly apotracheal, varying from scanty diffuse to abundant reticulate strands, and in some species tending to form long tangential bands. The differences between the samples studied by me are mostly quantitative. It seems impossible to indicate distinct limits between the genera.

JANSSONIUS (1926) described the wood anatomy of species of Diplospora, Hypobathrum, Petunga, Randia, Scyphiphora, and Zuccarinia. His data agree with those obtained from the samples studied by me in the vagueness of the growth rings characterised by a narrow zone of tangentially compressed fibres, in which the pores show a slightly smaller diameter. There are mostly more than 

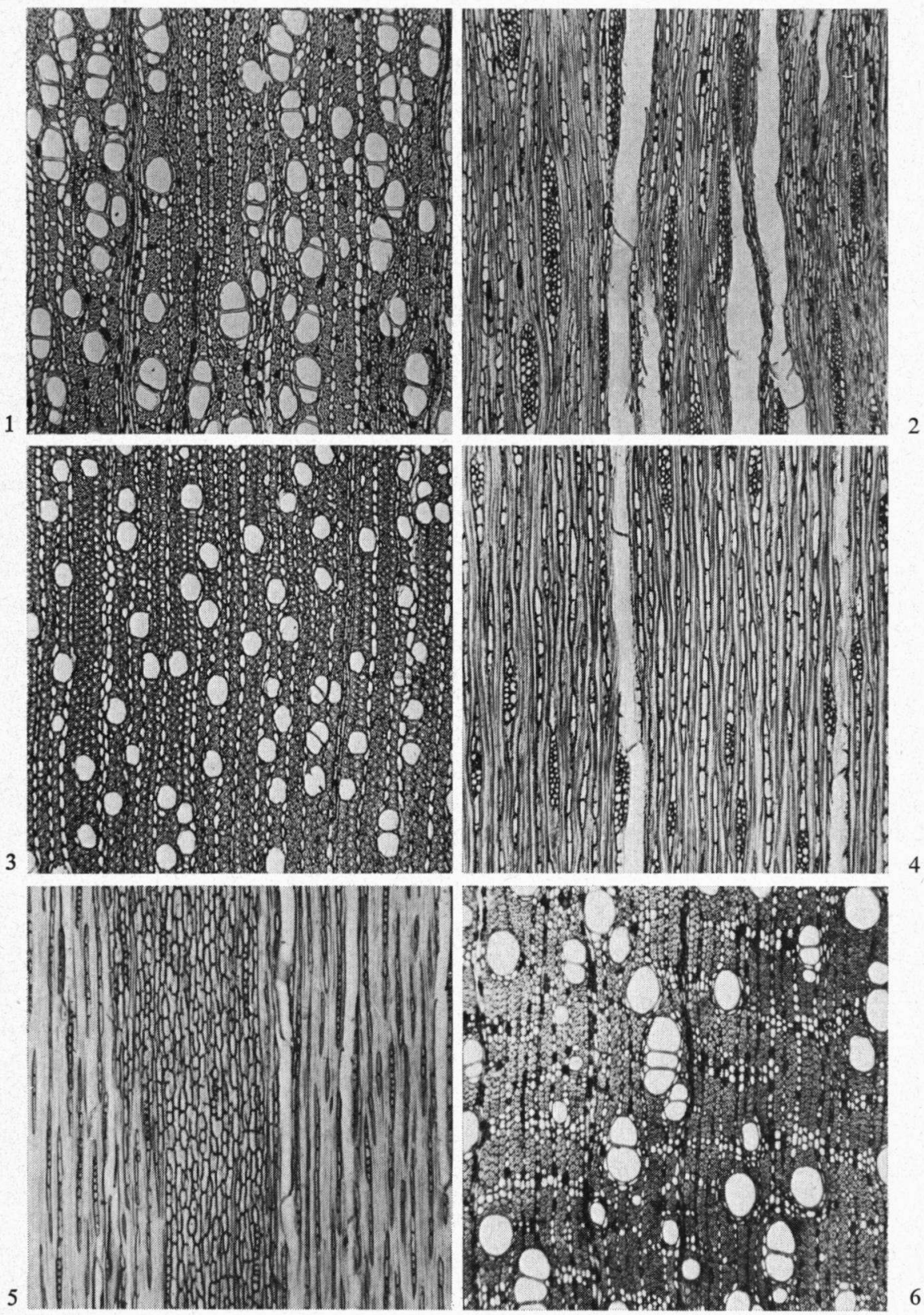

\section{Plate I.}

fig. 1. Amajoua corymbosa H.B.K. (Uw 7039) transv. sect. $45 \times$;

fig. 2. Amajoua corymbosa H.B.K. (Uw 7039) tang. sect. $45 \times$;

fig. 3. Gardenia remyi $\mathrm{H}$. Mann (Uw 4810) transv. sect. $45 \times$;

fig. 4. Gardenia remyi $\mathrm{H}$. Mann (Uw 4810 ) tang. sect. $45 \times$;

fig. 5. Alibertia myrciifolia K. Schum. (Uw 8087) tang. sect. $45 \times$;

fig. 6. Duroia eriopila L. f. (Uw 324) transv. sect. $45 \times$. 
20 vessels per sq. $\mathrm{mm}$, partly arranged in short radial multiples. The fibre tissue consists of fibre tracheids. The narrow rays are heterogeneous and the axial parenchyma is diffuse to reticulate.

RECORD \& GARRETT (1925) described the wood of Gardenia sp., the Siamese boxwood. In the presence of gelatinous fibre walls their data agree with those observed by me in G. thunbergii. They reported abundant conjugate or disjunctive elements in the upright ray cells. The data on the wood of Gardenia imperialis and of Massularia acuminata given by NoRMAND (1960) are not contradictory to the above.

The information given by MetCalfe \& ChalK (1950), on the contrary, deviates from my results in some respects. They reported for Kotchubaea "wide, separated parenchyma bands that tend to be associated with the vessels", whereas in the samples studied by me short and long, 1-3 cells wide bands occur. They cited PANSHIN (1932), who reported the presence of septate fibres in Scyphiphora, contrary to the description of Janssonius and to my own findings in the available wood sample. According to Metcalfe \& Chalk bordered pits are lacking in the non-septate fibres of Casasia. The sample of Casasia longipes studied in the present investigation has non-septate fibres which show bordered pits on the tangential and radial walls. Bothriospora and Fernelia are said to show septate fibres (MetCalfe \& CHALK 1950). (The material of Bothriospora present in Oxford consists of one slide of B. corymbosa Hook.f., Y 34074, which deviates in some other respects too from the wood anatomy of other Gardenieae, i.a. in the composition of the rays.)

Chang (1951) described the wood anatomy of Gardenia, Petunga, Randia, and Tarenna based upon the study of several species. In Petunga he reported rays which are up to 12 cells wide contrary to JANSSONIUS (1926), who reported 2- to 4-seriate rays. In the samples of Randia investigated by Chang some large tyloides occur. The height of the rays is said to be less than $1 \mathrm{~mm}$. In other respects his descriptions agree with those of the samples studied in the present investigation.

As for the genera the position of which in the Gardenieae is disputed, Hamelia Jacq., a genus which because of the presence of raphides was placed by BREMEKAMP (1966) in a separate tribe in the Rubioideae, shows some characteristics in which it resembles other genera of Rubioideae: the presence of septate libriform fibres, the absence of axial parenchyma, and in $H$. patens the 1- to 6-seriate rays which, moreover, are provided with some sheath cells.

Hillia Jacq., too, possesses raphides in the xylem. Moreover the sample studied by me differs from those of the true Gardenieae by the presence of septate libriform fibres with thick gelatinous cell walls, the multiseriate rays which are nearly all without uniseriate margins, and broad bands of axial parenchyma tending to include the vessels.

Between the three species of Posoqueria Aubl. there are only quantitative differences of minor importance. In the wood anatomy they agree in the presence of non-septate libriform fibres, more paratracheal parenchyma strands than are found in the other Gardenieae, and some vague tangential vessel rows 
(Metcalfe \& Chalk (1950), moreover, reported semi-ringporousness in the genus). In these characters Posoqueria differs from the Gardenieae.

Aulacocalyx Hook.f. is represented by $A$. jasminiflora and, if PeTIT's opinion (1962) that Aulacocalyx and Heinsenia K. Schum. are synonyms is correct, also by $H$. sylvestris. The samples studied by me are very similar in the anatomy of the wood and agree very well with the Gardenieae in the presence of numerous solitary vessels, fibre tracheids, 1- to 3-seriate rays with high uniseriate margins, and diffuse axial parenchyma tending to be reticulate.

Pentagonia Bth. (Plate III) differs from the Gardenieae in the septate libriform fibres, in the high and rather broad multiseriate rays mainly composed of square and upright cells, and in the absence of parenchyma.

Retiniphyllum H. \& B. is represented in the wood collection by four species. The genus consists of small shrubs, and the diameter of the samples varies from $1.5-4 \mathrm{~cm}$. So quantitative differences are of no value. In most respects, however, the samples studied by me are very similar and agree with those of the Gardenieae: the vessels are predominantly solitary, sometimes partly surrounded by parenchyma strands; the fibre tissue consists of fibre tracheids; the 2- to 4-seriate rays have high margins and many diffuse axial parenchyma strands occur.

The wood anatomy of Bertiera Aubl. and Heinsia DC. is discussed in 3.1.2., that of Tarenna Gaertn. and Tricalysia A. Rich. in 3.1.3.

\subsubsection{Mussaendeae}

Material was available of Gonzalagunia R. \& P., Gouldia A. Gray, Isertia Schreb., and Mussaenda L., genera, which are included in the Mussaendeae in all the literature studied by me, and of Acranthera Arn., Bertiera Aubl., Heinsia DC., Hippotis R. \& P., Mycetia Reinw., Pentagonia Bth., Schradera Vahl, Sommera Schlecht., and Urophyllum Wall. (including Leucolophus Brem., Pleiocarpidia K. Schum., and Maschalocorymbus Brem.). The inclusion of this last mentioned group of genera in the Mussaendeae has been disputed in the literature.

The samples of Isertia Schreb. studied by me were rather similar. Most species show vessels which are nearly exclusively solitary, fibre tracheids, rays which are composed of a low, mostly biseriate central part consisting of procumbent cells and high uniseriate margins which are composed of upright cells (Plate II), and scanty diffuse strands of axial parenchyma which sometimes form short bands between two rays. The rays in Isertia hypoleuca show only rarely uniseriate margins, whereas the procumbent cells form a 2- to 4-seriate part which is sometimes more than $1 \mathrm{~mm}$ high.

Beside by fibre tracheids and by a rather scanty diffuse and slightly reticulate axial parenchyma, Mussaenda sphaerocarpa, M. zenkeri and $M$. spec. (U 9258) are characterised by the arrangement of the vessels: contrary to the samples of Isertia studied by me in the samples of Mussaenda more than $50 \%$ of the vessels are arranged in radial multiples, partly 4-7 cells long (Plate II). This is in agreement with the description of $M$. frondosa given by Janssonius (1926). Chang (1951) mentioned for the three species studied by him that the radial multiples 

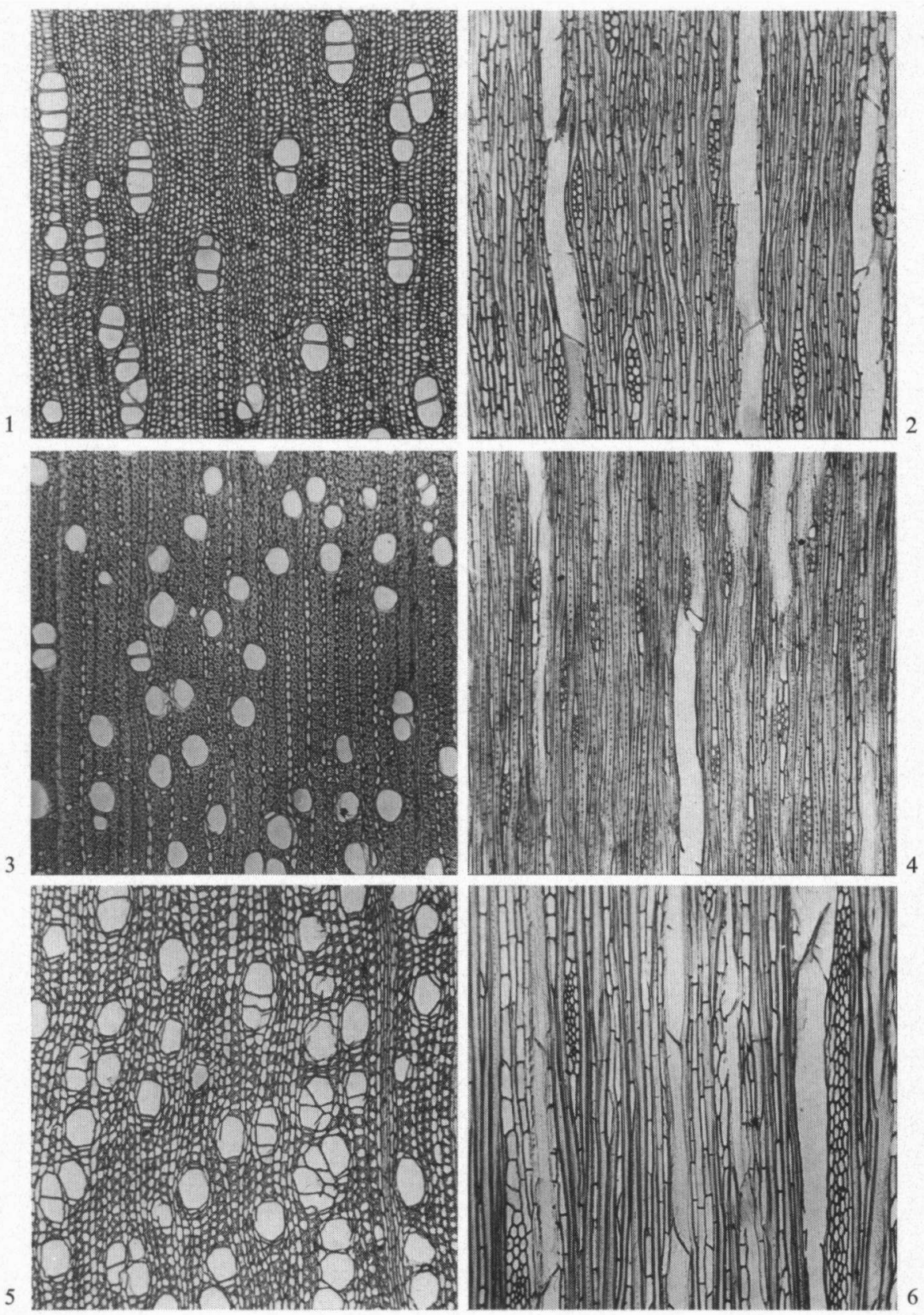

Plate II.

fig. 1. Mussaenda sphaerocarpa Mildbr. (Uw 14950) transv. sect. $45 \times$;

fig. 2. Mussaenda sphaerocarpa Mildbr. (Uw 14950) tang. sect. $45 \times$;

fig. 3. Isertia longifolia K. Schum. (Uw 9042) transv. sect. $45 \times$;

fig. 4. Isertia longifolia $\mathrm{K}$. Schum. (Uw 9042) tang. sect. $45 \times$;

fig. 5. Urophyllum glabrum Jack (Uw 16626) transv. sect. $45 \times$;

fig. 6. Urophyllum glabrum Jack (Uw 16626) tang. sect. $45 \times$. 
or chains of vessels are usually formed by 2-5 large vessels, followed by 5 or more smaller ones in tail-like arrangement, the diameter varying from about $150 \mu$ to less than $50 \mu$. He described 1- to 6-seriate rays composed mainly of square cells occasionally with sheathing upright cells, and occasionally with procumbent cells which are not much radially flattened. This agrees with the composition of the rays of $M$. zenkeri represented by a sample which is $1.5 \mathrm{~cm}$ in diameter.

Gonzalagunia R. \& P. was represented by a sample of G. spicata. The wood anatomy deviates from the samples of Mussaenda and Isertia studied by me in the short 2- to 3-seriate parts of the rays, which are composed of square and upright cells. Contrary to Metcalfe \& Chalk (1950) I did not observe the presence of septate fibres.

Gouldia axillaris and G. terminalis have vessels which are partly arranged in short radial multiples. The fibre tissue consists of fibre tracheids. The rays are 1- to 4-seriate, nearly exclusively composed of square and upright cells. The axial parenchyma is scanty, vasicentric and diffuse.

Acranthera longipes Merr., "herba robusta sed altitudine ignota" (BREMEKAMP 1947), was represented by a stem $1 \mathrm{~cm}$ in diameter. The vessels are partly arranged in radial multiples, sometimes forming a radial chain; the diameter is $40-50 \mu$. The rays are 1- to 5-seriate and composed of square and upright cells; sheath cells are abundant. The fibres are septate, thin-walled with spiral thickenings; the pits are scanty and without distinct borders. I did not observe axial parenchyma. CHANG's description (1951) of the wood of this species agrees rather well with mine. However, he did not report the presence of septa in the fibres. Remarkable is the abundance of starch grains.

Bertiera guianensis and $B$. racemosa show rays mainly composed of square and upright cells. In other characteristics there is a good agreement with Isertia (Plate II, III).

The wood anatomy of Heinsia jasminiflora and $H$. pulchella is qualitatively and quantitatively identical with that of the samples of Mussaenda studied by me.

Hippotis R. \& P., Pentagonia Bth. (Plate III), and Sommera Schlecht. are similar in the septate libriform fibres, the uni- and multiseriate rays composed of procumbent and square cells, and the absence of axial parenchyma. (CHANG 1951 reported in $P$. orthoneura Standl. "a single cell near the vessels"). METCALFE \& ChalK (1950) mention Sommera under the genera without axial parenchyma and with non-septate fibres.

Mycetia myrioneuron, represented by a sample of $2 \mathrm{~cm}$ in diameter, has predominantly solitary vessels, thin-walled and septate libriform fibres, uniand biseriate rays composed of square and upright cells, and some paratracheal parenchyma strands.

Schradera rotundata was discussed in KoeK-Noorman (1969b). In that paper the presence of libriform fibres was reported. The samples, however, show fibre tracheids which deviate much from the usual type: between each two adjacent fibres abundant bordered pits occur, with a round or oval aperture slightly smaller than the $5 \mu$ large border. 

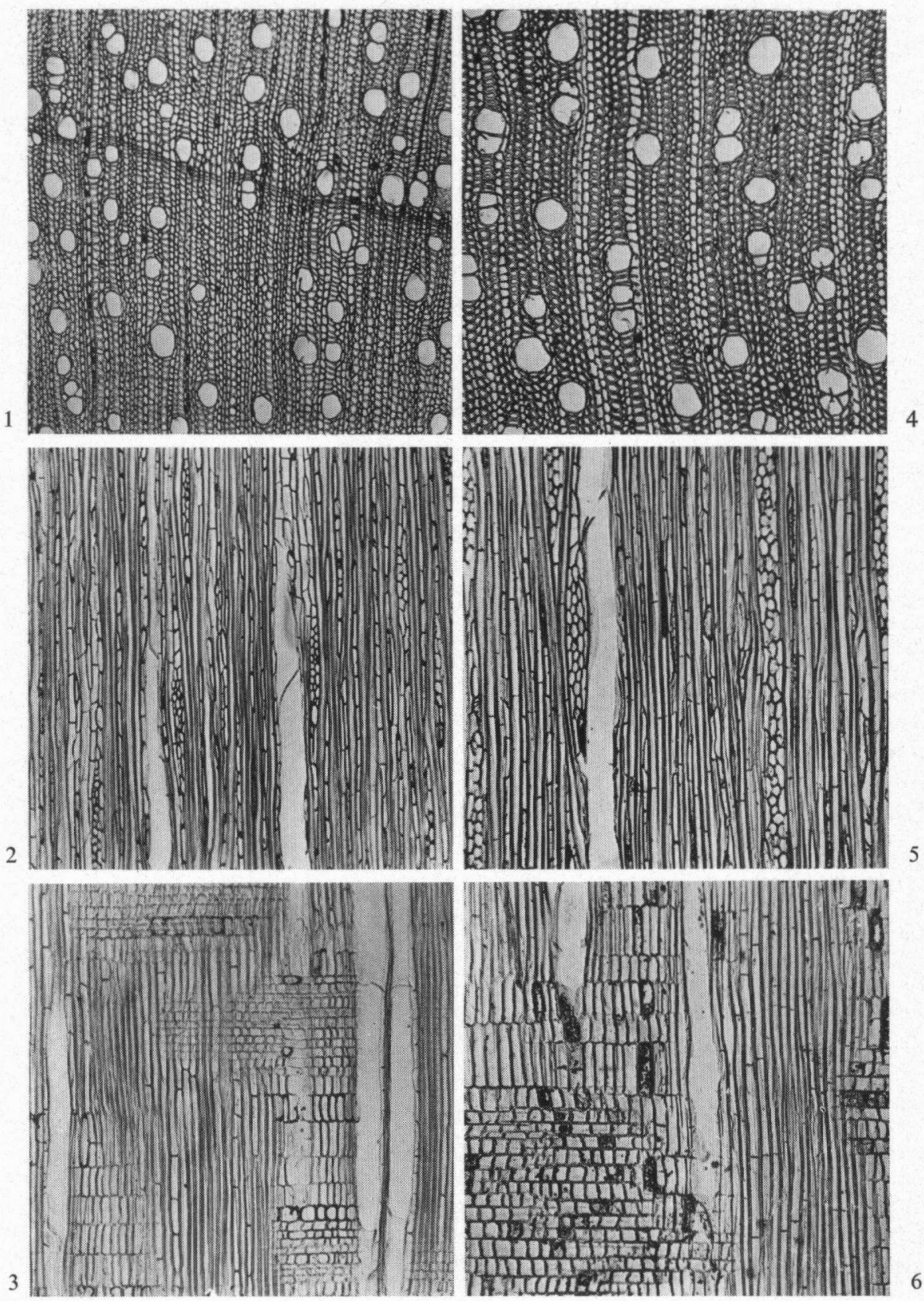

Plate III.

fig. 1. Bertiera racemosa K. Schum. (Uw 16622) transv. sect. $45 \times$;

fig. 2. Bertiera racemosa $\mathrm{K}$. Schum. (Uw 16622) tang. sect. $45 \times$;

fig. 3. Bertiera racemosa K. Schum. (Uw 16622) rad. sect. $45 \times$;

fig. 4. Pentagonia macrophylla Bth. (Uw 16625) transv. sect. $45 \times$;

fig. 5. Pentagonia macrophylla Bth. (Uw 16625) tang. sect. $45 \times$;

fig. 6. Pentagonia macrophylla Bth. (Uw 16625) rad. sect. $45 \times$. 
Urophyllum Wall. was represented by two species: $U$. glabrum and $U$. trifurcum. Besides, material of some nearly related genera was available, viz. from Leucolophus, Maschalocorymbus and Pleiocarpidia. All samples show thin-walled, more or less angular vessels which are partly arranged in radial multiples; fibre tracheids; rays with a multiseriate part composed of predominantly square and upright cells; and scanty paratracheal and sometimes abundant, diffuse parenchyma strands (Plate II). This agrees with the description of $U$. glabrum given by JANSSONIUS (1926) and with data reported by ChaNG (1951) based upon $U$. grandifolium. The spiral thickenings in the fibre tracheids of $U$. rahmatii observed by Chang agree with those found in $U$. trifurcum, in Pleiocarpidia assahanica, and P. sandahanica and in Leucolophus tobingensis.

\subsubsection{Ixoreae}

The wood anatomy of the available samples of Ixora, Pavetta, Rennellia, and Rutidea is very homogeneous. The vessels are exclusively or predominantly solitary, often very small and numerous. The fibre tissue consists of fibre tracheids. The rays are either exclusively uniseriate, or uni- and multiseriate, and in that case composed of a low, 2- to 4-seriate part of procumbent cells and long uniseriate margins of upright cells. The axial parenchyma is usually scanty and diffuse, but in some species for a small part paratracheal. In most samples small rhombic crystals occur in the axial parenchyma or in the procumbent upright or ray cells. The data obtained in the present investigation agree very well with the descriptions of species of Ixora and Pavetta given by JANSSONIUS (1926). The tyloides, scarcely occurring in the axial parenchyma cells of the samples of Ixora grandifolia and $I$. macrophylla studied by me, were reported by him for Pavetta indica var. montana. The descriptions of Ixora and Pavetta by CHANG (1951) agree completely with that given above.

The available samples of Tarenna and Tricalysia, with the exception of that of Tarenna incerta (see the remark made in 3.2.3. on the position of this species), agree very well with those of the genera mentioned above. (see table 1 ).

\subsection{Discussion of the classifications in the light of the similar- ities and differences in the wood anatomy}

\subsubsection{Delimitation of the Gardenieae (see also 3.1.1.)}

The Gardenieae sensu SCHUMANN (1897) include a number of genera which have been removed from this tribe by more recent authors. For instance, Hamelia Jacq. was placed by BREMEKAMP $(1954,1966)$ in a tribe of its own in the Rubioideae. This was supported by VERDCOURT (1958). The anatomy of the wood agrees with this view, because, beside other characteristics which are typical for the Rubioideae (KOEK-NOORMAN, 1969b), in one of the available samples raphides occur.

Posoqueria Aubl. was also removed from the Gardenieae by Bremekamp. Verdcourt agreed with him. Both authors suggested an isolated position within 


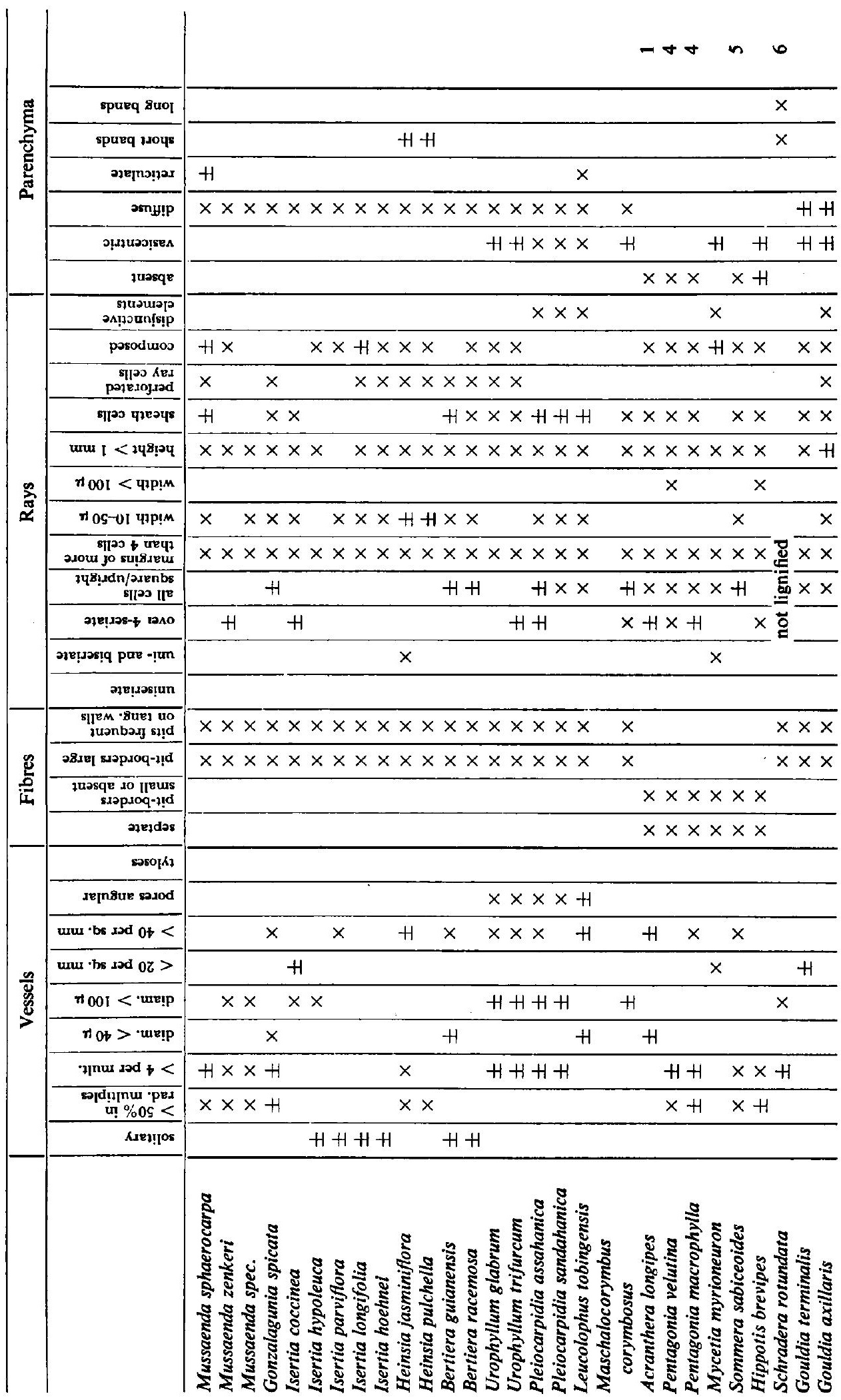




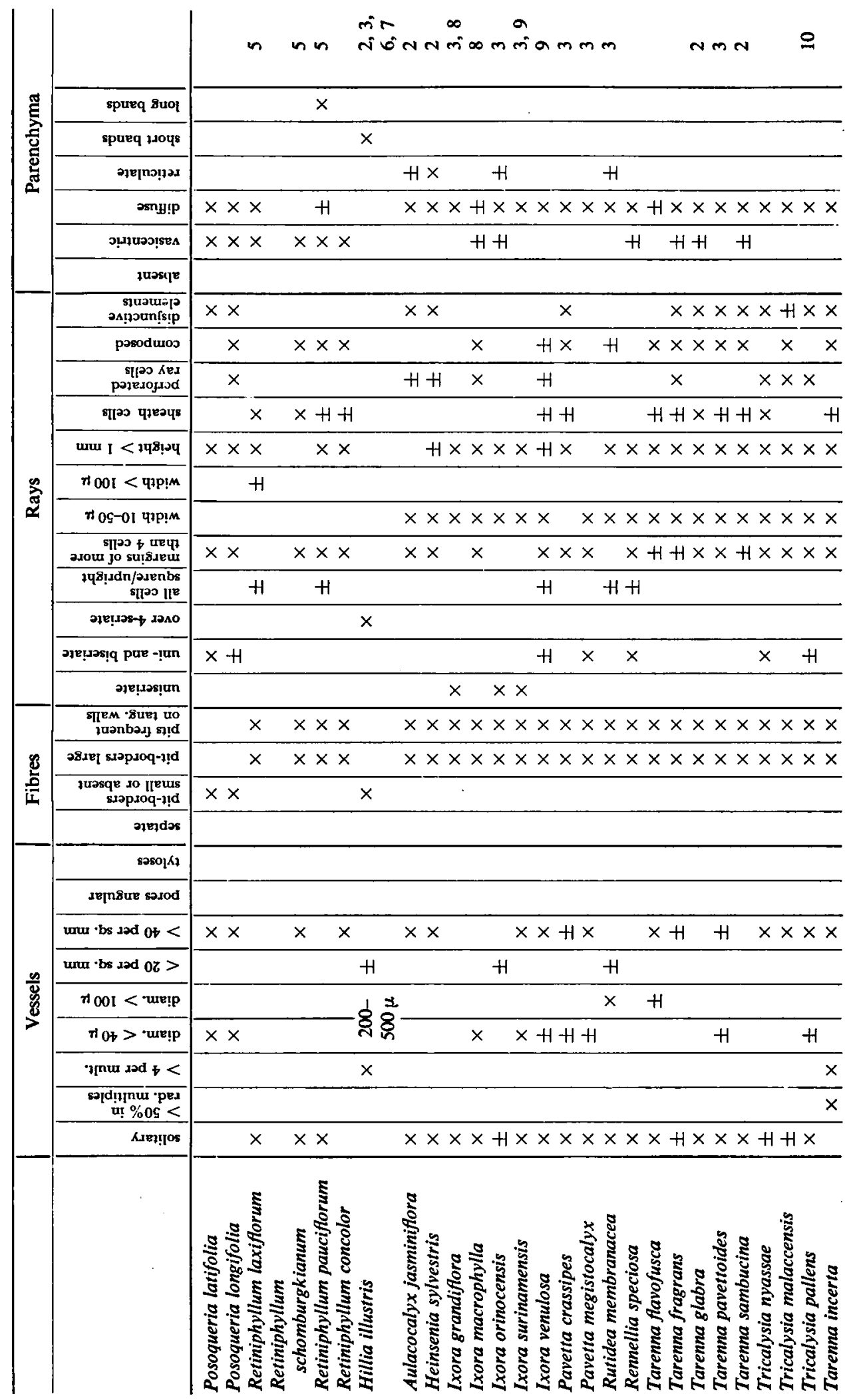




\section{Table 1.}

$x:$ the feature is present

$\pm:$ the feature is scarcely present, or exceptions occur

1: starch grains abundant

2: small rhombic crystals in procumbent ray cells

3: small rhombic crystals in axial parenchyma cells

4: crystal sand in ray cells

5: many gumlike inclusions in ray cells

6: raphides in upright ray cells

7: gelatinous fibre walls

8: styloids in axial parenchyma cells

9: many gum-like inclusions in vessels

10: small rhombic crystals in upright ray cells. 


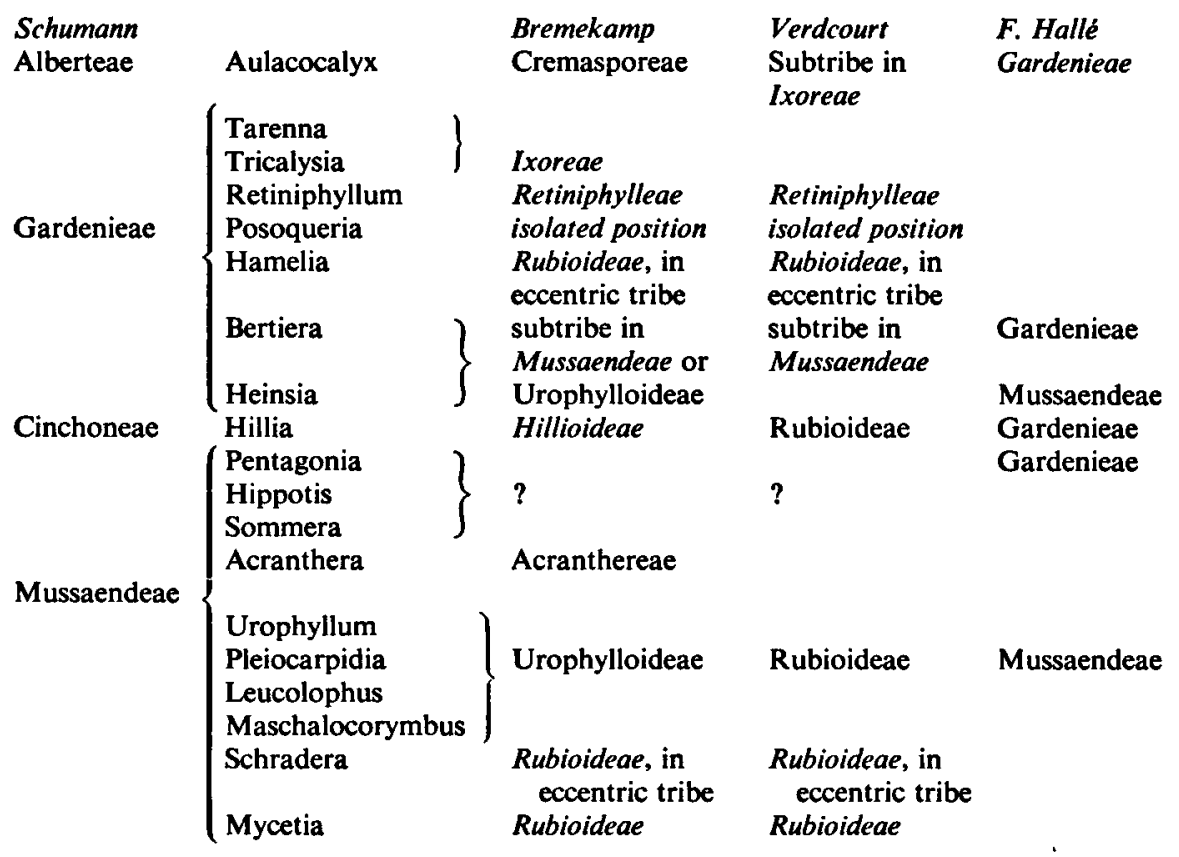

Survey of the position of some Rubiaceous genera according to Schumann, Bremekamp, Verdcourt, and Hallé.

Where the wood anatomy agrees with the opinion of one of these authors, this is indicated by printing in italics the name of the taxon to which they have been referred by him.

the family. Halle (1967) and Steyermark (1967) classed Posoqueria in the Gardenieae, but did not give arguments for this decision. Taking into consideration the great homogeneity of the Gardenieae studied by me, it is noteworthy that the three available species of Posoqueria deviate in some important points. The fact that the libriform fibres are non-septate forms a difference with those groups of the Rubiaceae showing septate libriform fibres: the Rubioideae, Guettardoideae, and some species of the Condamineae and Rondeletieae studied by me. Thus the wood anatomy supports the idea that Posoqueria occupies an isolated position within the family.

The genus Retiniphyllum Humb. \& Bonpl. was placed in a tribe of its own by BREMEKAMP (1934a) and VerdCOURT (1958). Verdcourt included this tribe in the Cinchonoideae. The wood samples support this opinion. In most characteristics the species studied by me agree with the Gardenieae. They differ in the presence of scanty paratracheal parenchyma strands and in the composition of the multiseriate parts of the rays, these consist of square and procumbent cells which are not much radially flattened. 
Hillia Jacq., placed in the Cinchoneae by SCHumanN (1897), was considered to belong to the Gardenieae by HaLlé (1967). He reported the presence of raphides but considered that character not important enough to justify classification in a tribe of its own in the Rubioideae (VERDCOURT 1958) or in a separate subfamily Hillioideae (BREMEKAMP 1966). The wood anatomical characters of Hillia illustris, however, deviate strongly from those of the Cinchoneae (KOEKNoORman 1970), Gardenieae and Mussaendeae studied by me and seem to justify its classification in a separate position.

Aulacocalyx Hook.f. = Heinsenia K. Schum., classified in the Alberteae by SchumanN (1897) (cf. Cremasporeae sensu Bremekamp) was mentioned by Hallé (1967) in his treatment of the Gardenieae. Verdcourt (1958) considered this genus to be so nearly related to Ixora that he classified it in a subtribe within the Ixoreae. Wood anatomically there is a good agreement with the Gardenieae. The same applies to Tarenna Gaertn. and Tricalysia A. Rich., genera which were removed from the Gardenieae into the Ixoreae by Bremekamp. In 3.2.3. I shall recur to these three genera.

Bertiera Aubl., Heinsia DC., and Pentagonia Bth. are dealt with in 3.2.2.

\subsubsection{Delimitation of the Mussaendeae (see also 3.1.2.)}

The Mussaendeae sensu BREMEKAMP (1966) and VERDCOURT (1958) include only a small number of the genera referred to the Mussaendeae by ScHUMANN (1897). They retain in this tribe the genera Isertia Schreb., Mussaenda L., Cassupa Humb. \& Bonpl., “and perhaps a few other ones” (BREMEKamp 1966).

The genera Isertia and Mussaenda differ in the percentage of vessels which are arranged in radial multiples. (In most species of Isertia the vessels are nearly exclusively solitary, whereas in the species of Mussaenda more than $50 \%$ of the vessels are arranged in radial multiples.) In the other wood characteristics they agree rather well, and in the wood anatomy therefore no reason can be found to doubt the rather close affinity between these two genera.

Gonzalagunia R. \& P. is one of the small genera of the Mussaendeae sensu stricto. Contrary to Isertia and the samples of Mussaenda studied by me, $G$. spicata shows rays which are nearly exclusively composed of square and upright cells. As for some species of Mussaenda the same composition has been reported (CHANG 1951) and as, furthermore, the sample of $G$. spicata had a diameter of only $2 \mathrm{~cm}$, this difference in the composition of the rays is no reason to dispute the affinity between Gonzalagunia and the other genera.

Gouldia A. Gray also is said to be allied to Mussaenda. The wood characteristics agree enough to accept this view (see table 1).

BREMEKAMP (1966) removed a number of genera from the Mussaendeae because of the presence of raphides, or because of a deviating structure of the testa cells. He classified them in the Rubioideae and Urophylloideae, respectively. Schradera Vahl and Mycetia Reinw., included in the first mentioned group, are represented by one sample each. The wood structure of Mycetia myrioneuron is quite different from that of Isertia, Mussaenda, Gouldia, and Gonzalagunia, and agrees better with the structure of the Rubioideae studied by me, viz. in the 
presence of libriform fibres, in the composition of the rays (square and upright cells in uni- and biseriate parts), and the presence of scanty paratracheal parenchyma strands. The presence of raphides in the wood of Schradera rotundata fits in with Bremekamp's idea of classifying the genus in the Rubioideae. He remarked that the Schradereae are "the most deviating tribe among the Rubioideae". For the wood anatomy the same can be stated. With the Mussaendeae, however, the liana studied by me has less agreement.

Acranthera Arn. was removed from the Mussaendeae into a tribe of its own in the Ixoroideae by BREMEKAMP (1947). In a personal communication BAKHUIZEN VAN DEN BRINK suggested a position near the herbaceous Rubioideae. The only available sample of $A$. longipes shows some characteristics which fit in better with the Rubioideae studied by me than with the Mussaendeae.

Urophyllum Wall. and its nearest allies were classified in a separate subfamily by BREMEKAMP (1940). VERDCOURT (1958), who contrary to BREMEKAMP (1966) reported the presence of raphides in this group, included them in the Rubioideae. The most important difference between Urophyllum, Pleiocarpidia, Leucolophus, and Maschalocorymbus and the Mussaendeae seems to be the composition of the rays, which have high multiseriate parts composed of square and upright cells sometimes up to 6 cells wide. Remarkable are also the spiral thickenings of the fibre tracheids and the angular pores. The agreement with the Rubioideae is less close, thus Verdcourt's idea is not supported by the wood anatomy. Before the creation of the subfamily Urophylloideae and its delimitation can be discussed in the light of the wood anatomy, it will be necessary to study more material of other related genera.

Heinsia DC. and Bertiera Aubl., placed in the Gardenieae by SchumanN (1897), were considered to form a subtribe in the Mussaendeae by VERDCOURT (1958). BREMEKAMP (1966) suggested that these genera may belong to his Urophylloideae. HALlÉ (1961) classified Heinsia in the Mussaendeae and Bertiera in the Gardenieae (1967), be it in a marginal position. The wood of the species of Heinsia studied by me can not be distinguished from that of the species of Mussaenda, and it is improbable that these genera are not closely related. Bertiera agrees with Isertia in the predominantly solitary vessels and with Gonzalagunia in the composition of the rays.

Pentagonia Bth. was included in Hallés study of the Gardenieae (1967). BremeKamp (1966) doubted whether Pentagonia might be regarded as related to Hippotis and Sommera, genera which are considered to be near allies by SchumanN (1897). As stated in 3.1.2., the species of the three genera studied by me agree rather well. They are very similar to the Rubioideae studied by me (KoEK-NoORMAN 1969b). However, I observed no raphides. Further investigations are necessary to decide whether these crystals, the presence of which is required for an inclusion in the Rubioideae (BREMEKAMP 1966), are also absent in other parts of the plants.

\subsubsection{Delimitation of the Ixoreae (see also 3.1.3.)}

Because of the agreement in the structure of the drupe the Ixoreae sensu 
SCHUMANN (1897) were enlarged with some genera by BREMEKAMP (1934b), i.a. with Tarenna Gaertn. and Tricalysia A. Rich. which had been included in the Gardenieae by Schumann. The wood structure of Tarenna and Tricalysia fits in very well with that of the other Ixoreae studied by me. The small variation within the Ixoreae, however, does not exceed that within the Gardenieae. It seems impossible to decide by means of the wood anatomy whether Tarenna and Tricalysia are to be referred to the Gardenieae or to the Ixoreae. Tarenna incerta, the only species with about $60 \%$ of the vessels arranged in radial multiples, is considered to be identical with Randia wallichii as stated by BAKHUIZEN VAN DEN BRINK in a personal communication. All species of Randia studied by me show nearly exclusively solitary vessels except $R$. wallichii which is wood anatomically rather similar with $T$. incerta. Within the Gardenieae however, the characteristic of radial multiples occurs in several genera.

Aulacocalyx Hook.f., classified by SCHUMANN (1897) in the Alberteae, was placed in a subtribe in the Ixoreae by VerdCOURT (1958). HALLÉ (1967) included this genus in the Gardenieae. PETIT (1962) combined Heinsenia K. Schum. and Aulacocalyx in one genus but did not discuss its relationship with other Rubiaceae. The wood samples of $H$. sylvestris and $A$. jasminiflora show only minor quantitative differences. As for Aulacocalyx, the same can be stated as for Tarenna and Tricalysia: the wood characteristics do not exceed those of the Ixoreae. Thus by means of these characteristics a decision about classification either in the Gardenieae or in the Ixoreae can not be made.

\subsubsection{Relationship between Gardenieae, Ixoreae, and Mussaendeae}

As stated in 3.2.3. the wood anatomy of the Gardenieae and the Ixoreae studied by me is very similar. The Gardenieae show some variation in the arrangement of the vessels, the width of the rays, and the distribution of the axial parenchyma (see table I). The very small variation within the Ixoreae does not exceed that within the Gardenieae. This supports the classifications of VerDCOURT (1958) and BREMEKAMP $(1953,1966)$, in which the Gardenieae and Ixoreae are considered to be nearly related and are therefore placed in one subfamily, contrary to those of ScHUMANN (1897) and his predecessors. The wood anatomy of the Mussaendeae sensu Bremekamp (Mussaenda, Isertia, Gouldia, Gonzalagunia) studied here deviates in some respects from that of the Gardenieae and Ixoreae (for instance by the frequent occurrence of radial multiples of vessels in Mussaenda, and by the structure of the rays, which are often predominantly composed of square and upright cells). The differences, however, are not so large that they can be adduced in support of the distinction between Ixoroideae and Cinchonoideae made by Bremekamp. This question will be studied in subsequent investigations of the other tribes of these subfamilies.

\section{ACKNOWLEDGEMENT}

The author is much indebted to Prof. Dr. C. E. B. Bremekamp for his correcting of the English text, to miss J. Holla for her assistance in the preparation of the manuscript and to the Cura- 
tors of the woodcollections at Amsterdam (Royal Trop. Inst.), Leiden (Rijksherbarium), Madison (U.S. For. Prod. Lab.), Reinbek, and Washington (Smiths. Inst.) for providing her with valuable wood specimens. Furthermore she wishes to thank the Curators and staff members of the Jodrell Laboratory, Kew, the Commonwealth Forestry Institute, Oxford, and the Forest Products Research Laboratory, Princes Risborough, for their kind assistance during her visit to the wood collections of these institutes in 1970.

\section{MATERIAL STUDIED*}

Acranthera longipes Merr.: Indonesia - Uw 18412 (USw 27547, Sumatra; diam. $1 \mathrm{~cm}$ ). Alibertia acuminata (Bth.) Sandwith: British Guiana - Uw 1074 (For. Dept. 2403).

Amaioua corymbosa H. B. K.: Panama - Uw 7039 (USw 73, U.S. Nat. Herb. 715490).

Amaralia streptocaulon K. Schum.: Cameroun - Uw 9428 (Breteler 1867, Doumé; liana, diam. $5 \mathrm{~cm}$ ).

Aulacocalyx jasminiflora Hook. f.: Ghana - Uw 17777 (Vigne 3149); Liberia - Uw 18442 (SJRw 13785, Cooper 142; diam. $3.5 \mathrm{~cm}$ ).

Bertiera guianensis Aubl.: Brazil - Uw 7867 (Krukoff 6677; diam. 4 cm); Suriname - Uw 12106 (v. Donselaar 3402, Brokopondo; treelet, diam. 1.5 cm); Panama - Uw 16621 (Cooper 586).

Bertiera racemosa K. Schum.: Liberia - Uw 16622 (Cooper 258).

Borojoa stipularis (Ducke) Cuatr.: Brazil - Uw 16199 (Krukoff 8470; diam. $6 \mathrm{~cm}$ ).

Casasia clusiifolia Urb.: Florida - Uw 17747 (F.P.R.L. 12826).

Casasia longipes Urb.: Jamaica - Uw 8333 (USw 5959; diam. $5 \mathrm{~cm}$ ).

Duroia fusifera Hook. f. ex Schum.: Venezuela - Uw 12235 (Breteler 4843, Sipapó R.; tree, $8 \mathrm{~m}$ high, diam. $18 \mathrm{~cm}$ ).

Duroia hirsuta (P. \& E.) Schum.; Brazil - Uw 7734 (Krukoff 6448; large tree); Uw 16209 (Krukoff 8631; diam. $5 \mathrm{~cm}$ ); Uw 16231 (Krukoff 8954; diam. $3.5 \mathrm{~cm}$ ).

Duroia saccifera (Mart.) Hook. f.: Brazil - Uw 8040 (Krukoff 6911; diam. $3.5 \mathrm{~cm}$ ).

Galiniera coffeoides Delile: East Africa - Uw 15916 (Schlieben 274; diam. $6 \mathrm{~cm}$ ).

Gardenia remyi H. Mann: Hawaiian Islands - Uw 4810 (K. Korte, Yale 49356; large tree).

Gardenia riparia K. Schum.: East Africa - Uw 15948 (Schlieben 1734; diam. $8 \mathrm{~cm}$ ).

Gardenia thunbergii L. f.: East Africa - Uw 15851 (Schlieben 1801; diam. $8 \mathrm{~cm}$ ).

Genipa caruto H.B.K.: Panama - Uw 7028 (USw 54, U.S. Nat. Herb. 679845; large tree).

Gonzalagunia spicata (Lam.) Gomez: Dominica - Uw 15430 (Chambers 2670).

Gouldia axillaris Wawra: Hawaiian Islands - Uw 18440 (SJRw 26526; diam. $2 \mathrm{~cm}$ ).

Gouldia terminalis (Hook. \& Arn.) Hillebr.: Hawaii Islands - Uw 18439 (SJRw 52721; diam. $2.5 \mathrm{~cm}$ ); Uw 18547 (Stern \& Herbst 463; diam. $0.5 \mathrm{~cm}$ ); Uw 18562 (Stern \& Herbst 479; diam. $2.5 \mathrm{~cm}$ ); Uw 18565 (Stern \& Herbst 482; diam. $2 \mathrm{~cm}$ ).

Hamelia patens Jacq.: Brazil - Uw 14186 (Lindeman \& H. de Haas 4840, Paraná; treelet, diam. $2.7 \mathrm{~cm}$ ); Florida - Uw 17765 (PRFw 12802).

Heinsenia sylvestris S. Moore: Rhodesia - Uw 17726 (Swynnerton; diam. $7 \mathrm{~cm}$ ).

Heinsia jasminiflora DC.: Liberia - Uw 16623 (Cooper 102).

Heinsia pulchella K. Schum.: Cameroun - Uw 9490 (Breteler 2324, Yaoundé; tree, $10 \mathrm{~m}$ high, diam. $16 \mathrm{~cm}$ ); Liberia - Uw 16624 (Cooper 210); Uw 18406 (USw 4531).

Hippotis brevipes Spruce: Peru - Uw 17892 (MADw 6945).

lbetralia surinamensis Brem.: Suriname - Uw 1706 (Lanjouw \& Lindeman 2338, Nassau Mountains; diam. $2.5 \mathrm{~cm}$ ).

Isertia hoehnei Krause: Brazil - Uw 16157 (Krukoff 8064).

Isertia longifola K. Schum.: Brazil - Uw 9042 (Maguire c.s. 51784, Rio Araguari, Amapá; diam. $13 \mathrm{~cm}$ ).

Ixora casei Hance: Ponape - Uw 16700 (Miller 6693).

Ixora grandiflora Z. \& M.: Indonesia - Uw 17766 (Krukoff 4397, Sumatra).

Ixora macrophylla Bartl. ex DC: - Uw 16276 (RTIw 18 - 68 - 262).

Ixora triantha Volk.: Mariana Islands - Uw 16688 (Dutton 129).

* Abbreviations are according to STERN, Index Xylariorum (1967). 
Ixora venulosa Bth.: Brazil - Uw 13155 (Lindeman \& H. de Haas 1541, Paraná; treelet, diam. $5 \mathrm{~cm}$ ).

Kotchubaea semisericea Ducke: Brazil - Uw 16185 (Krukoff 8372; large tree).

Leptactinia hexamera K. Schum.: East Africa - Uw 15884 (Schlieben 16; diam. $6 \mathrm{~cm}$ ).

Leucolophus tobingensis (Miq.) Brem.: Indonesia - Uw 18402 (USw 27480, Sumatra; diam. $1.5 \mathrm{~cm})$.

Maschalocorymbus corymbosus (Blume) Brem.: Indonesia - Uw 17903 (Jacobs 5290, Borneo).

Mussaenda sphaerocarpa Mildbr.: East Africa - Uw 14950 (RTIw TP 4374 - 45; diam. 7 cm); Uw 15543 (Schlieben 1605; diam. $6.5 \mathrm{~cm}$ ).

Mussaenda zenkeri Wernh.: Cameroun - Uw 9265 (Breteler 784, Bertoua; liana, diam. $1.5 \mathrm{~cm}$ ).

Mussaenda spec.: Cameroun - Uw 9258 (Breteler 556, Adamaoua; liana, diam. $4 \mathrm{~cm}$ ).

Mycetia myrioneuron Merr.: Indonesia - Uw 18403 (USw 28852, Sumatra; diam. $1.2 \mathrm{~cm}$ ).

Pavetta crassipes K. Schum.: Nigeria - Uw 17800 (Jones 6348 = FHOw 13410; diam. $3 \mathrm{~cm}$ ).

Pavetta megistocalyx K. Krause: Ghana - Uw 17771 (Vigne 2966).

Pentagonia macrophylla Benth.: Panama - Uw 16625 (Cooper \& Slater 122); Uw 17730 (USw 119; diam. $2.5 \mathrm{~cm}$ ).

Pentagonia velutina Standl.: Peru - Uw 18460 (MADw 5280, Puerto Arturo, R. Huallaga; diam. $6 \mathrm{~cm}$ ).

Pleiocarpidia assahanica Brem.: Indonesia - Uw 18410 (USw 28886, Sumatra; diam. $2 \mathrm{~cm}$ ).

Pleiocarpidia sandahanica Brem.: Indonesia - Uw 17901 (Jacobs 5291, Borneo; diam. $12 \mathrm{~cm}$ ).

Randia dumetorum Lam.: East Africa - Uw 15835 (Schlieben 1783; diam. $6 \mathrm{~cm}$ ).

Randia sericantha K. Schum.: East Africa - Uw 15877 (Schlieben 1852; diam. $7 \mathrm{~cm}$ ).

Randia wallichii Hook. f.: Indonesia - Uw 17906 (BW 7231, New Guinea; large tree);Uw 18289 (BW 13515, New Guinea; large tree).

Rennellia speciosa Hook. f.: Malaysia - Uw 17805 (Pickles 3720, Sarawak).

Rennellia spec.: Indonesia - Uw 17896 (Fuchs 21358, Borneo; diam. $4.5 \times 6 \mathrm{~cm}$ ).

Retiniphyllum concolor (Spr. ex Bth.) Muell. Arg.: Venezuela - Uw 18628 (Wurdack \& Addersley 43234, Terr. Amazonas).

Retiniphyllum pauciflorum Kunth. ex Krause: Venezuela - Uw 18630 (Wurdack \& Addersley 42752, Terr. Amazonas).

Rothmannia urcelliformis (Schweinfl. ex Hiern) Bullock ex Robyns: Ethiopia - Uw 14779 (Meyer 8819; diam. $6 \mathrm{~cm}$ ).

Rothmannia whitfieldii (Lindley) Dandy: Ivory Coast - Uw 10885 (Leeuwenberg 4110, near Guéyo; treelet, $8 \mathrm{~cm}$ high, diam. $8 \mathrm{~cm}$ ).

Rutidea membranacea Hiern: Cameroun - Uw 9322 (Breteler 1406, Ebaka; liana, diam. 2.5 $\mathrm{cm}$ ).

Sommera sabiceoides Schum.: Peru - Uw 17889 (MADw 1810; diam. 4 cm); Uw 17890 (MADw 2076; diam. $2.5 \mathrm{~cm}$ ); Uw 17891 (MADw 2664; diam. $3 \mathrm{~cm}$ ).

Stachyarrhena acuminata Standley: Brazil - Uw 9607 (Maguire c.s. 51403).

Tarenna flavo-fusca (K. Schum.) S. Moore: Cameroun - Uw 9510 (Breteler 2423, Bertoua; liana, diam. $3 \mathrm{~cm}$ ); Ivory Coast - Uw 10884 (Leeuwenberg 4158, La Mé R; liana, diam. $1.5 \mathrm{~cm})$.

Tarenna fragrans Koord. \& Valet.: Indonesia - Uw 17810 (FHOw 8091, Malaya); Uw 18455 (SJRw 31073, Java).

Tarenna glabra Merr.: Mariana Islands - Uw 18453 (SJRw 33235; diam. $3.5 \mathrm{~cm}$ ).

Tarenna incerta Koord. \& Valet.: China - Uw 18454 (SJRw 29567, Ngai Yuen, Hainan; large tree).

Tarenna pavettoides (Harv.) Sim.: Rhodesia - Uw 17729 (Coll. Swynnerton; diam. $8 \mathrm{~cm}$ ).

Tarenna sambucina Sch. \& Lauterb.: Fiji Islands - Uw 18456 (SJRw 28264; diam. $6 \mathrm{~cm}$ ).

Tocoyena guianensis K. Schum.: Brazil - Uw 16913 (Maguire c.s. 48072; diam. $9 \mathrm{~cm}$ ).

Tricalysia malaccensis Hook. f.: Indonesia - Uw 17813(For. Dept. $445=$ FHOw 7625, Malaya).

Tricalysia nyassae Hiern: Tanganyika - Uw 15491 (Schlieben 1509; diam. 6 cm); Uw 18457 (SJRw 23392; diam. $4.5 \mathrm{~cm}$ ).

Tricalysia pallens Hiern: Ghana - Uw 17814 (Vigne 2653; diam. $4.5 \mathrm{~cm}$ ).

Tricalysia spec.: Cameroun - Uw 9255 (Breteler 538, Adamaoua; treelet, diam. $5 \mathrm{~cm}$ ); Uw 9317 
(Breteler 1390, Bertoua; tree, $15 \mathrm{~m}$ high, diam. $20 \mathrm{~cm}$ ).

Urophyllum glabrum Jack: Malaysia - Uw 16626 (Pickles 3670, Borneo, Sarawak; diam. $4.5 \mathrm{~cm})$.

Urophyllum trifurcum Pears: Malaysia - Uw 16627 (Pickles 3762, Borneo, Sarawak; diam. $5 \mathrm{~cm}$ ).

\section{REFERENCES}

Bentham, G. \& W. J. Hooker (1873): Genera Plantarum II (7). London.

BremeKamp, C. E. B. (1934a): Notes on the Rubiaceae of Surinam. Rec. Trav. Bot. Néerl. 31 : 248-308.

- (1934b): A monograph of the genus Pavetta L. Fedde Repert. 37: 1-108.

- (1940): On Urophyllum Wall. (Rub.) and its nearest allies. Rec. Trav. Bot. Néerl. 37: 171-197.

- (1947): A monograph of the genus Acranthera Arn. ex Meissn. (Rub.). J. Arn. Arb. 28 (3): 261-308.

- (1954): Rapports et Communications aux sections 2, 4, 5 et 6. 8ième Congres de Botanique, 113-114.

- (1966): Remarks on the position, the delimitation and the subdivision of the Rubiaceae. Acta Bot. Neerl. 15: 1-33.

Chang, Ying-Pe (1951): Anatomy of wood and bark in the Rubiaceae. Diss. Manuscr. Univ. of Michigan.

HallÉ, F. (1961): Contribution a l'étude biologique et taxonomique des Mussaendeae (Rub.) d'Afrique tropicale. Adansonia 1 (2): 266-298.

- (1967): Etude biologique et morphologique de la tribu des Gardeniées (Rub.). Memoire ORSTOM 22.

JANSSONIUS, H. H. (1926): Mikrographie des Holzes der auf Java vorkommenden Baumarten. IV. Leiden.

KoEK-NoORMAN, J. (1969a): A contribution to the wood anatomy of South American (chiefly Suriname) Rubiaceae. I. Acta Bot. Neerl. 18: 108-123.

- (1969b): A contribution to the wood anatomy of South American (chiefly Suriname) Rubiaceae. II. Acta Bot. Neerl. 18: 377-395.

- (1970): A contribution to the wood anatomy of the Cinchoneae, Coptosapelteae and Naucleeae (Rubiaceae). Acta Bot. Neerl. 19: 154-164.

MetCALfe, C. R. \& L. ChalK (1950): Anatomy of the Dicotyledons. Oxford.

Normand, D. (1960): Atlas des bois de la Côte d'Ivoire. Nogent-sur-Marne.

PANSHIN, A. J. (1932): An anatomical study of the woods of the Philippine mangrove swamps. Philippine J. Sci. 48: 143-207.

PETIT, E. (1962): Rubiaceae africanae IX - Notes sur les genres Aidia, Atractogyne, Aulacocalyx, Batopedina, Gaertnera, Morinda, Mussaenda, Nauclea, Sabicea, Schizocolea et Tricalysia. Bull. J. Bot. Brux. 32 (2): 173-185.

Record, S. J. \& G. A. Garrett (1925): Boxwoods. New Haven.

Schumann, K. (1897): in A. Engler \& K. Prantl, Die natürlichen Pflanzenfamilien. IV (4). Leipzig.

SteYermarK, J. A. (1965): in B. MAGUIRE et al. The botany of the Guyana Highland VI. Mem. New York Bot. Gard. 12 (3): 178-285.

- (1967): The botany of the Guyana Highland VII. Mem. New York Bot. Gard. 17 (1): $230-436$.

VerdCourt, Ph. D. (1958): Remarks on the classification of the Rubiaceae. Bull. J. Bot. Brux. 28: 209-290. 